\title{
THE EXTINCTION AND SURVIVAL OF BIRDS - 65 MILLION YEARS AGO
}

\author{
TIM T. TOKARYK, Saskatchewan Museum of Natural History, 2340 Albert \\ Street, Regina, Saskatchewan. S4P 3V7
}

Extinction and evolution are not separable. For a species to evolve and survive it must be able to occupy a niche in the ecological system that is available (most likely due to an altered environment). Otherwise the species will become a mere glitch in the evolutionary record. Thus, extinction is an important partner of evolution. Historically, however, since Darwin's masterpiece On the Origin of Species, more emphasis has been placed on "evolution" than on "extinction" (at least until the past few decades). Two recent phenomena have evened the scales of discussion: one, that humans have the ability to exterminate species from the face of the earth; and two, a paper published in Science in 1980 announcing, with physical evidence for the first time ever, a specific cause of the extinction of the dinosaurs and other organisms 65 million years ago, at the end of the Cretaceous Period. ${ }^{1}$

If there seems to be little connection between extinction and evolution, let me explain. Evolution has traditionally been viewed as a slow, gradual process (again, until relatively recently). What Luis Alvarez and his team did in 1980 was to state that nearly $70 \%$ of all species became extinct suddenly at the end of the Cretaceous Period in a time frame of several months to a few years, as a result of an extraterrestrial impact. This disturbed gradualists (neo-Darwinians) on two points. Firstly, Alvarez envisioned an extremely abrupt extinction. A few months is a short period of time by anyone's standards, especially geologists who generally have a much longer running timepiece. Secondly, the theory introduces an external force that shapes evolution. If it were not for the impact of an extraterrestrial body, we would not be here, at least in our present form. The Alvarez team has reintroduced the term "extinction" into our evolutionary vocabulary and has added a descriptor - mass extinction.

This brings me to the main focus of this article - birds. For the most part dinosaurs have been the centre of attention in discussions of Cretaceous extinction. Two groups 1 have noticed little information about are insects and birds. Fortunately, a month or so ago I came across an article by Jarzenbowski of the Booth Museum of Natural History, England, where extinction of insects was the main focus of discussion. ${ }^{9}$ Yet, there has been little discussion of what happened to the birds. Storrs Olson has stated that the Late Cretaceous avian fauna resembles the mammalian record and supports a catastrophic mass extinction. ${ }^{17}$ By looking at the fossil record in more 
detail we see that this statement is too general.

Table 1 illustrates the North American avian record of the last 30 million years of the Cretaceous Period. Most noticeable is that most of the avian fauna is found near the end of the Cretaceous between 65 and 74 million years ago. This fauna is composed almost exclusively of shorebirds within the order Charadriiformes. Yet none of the Cretaceous birds can be assigned to modern families. ${ }^{17}$

Let us look a little further into the past. During most of the late Cretaceous (between 110 and 65 million years ago) North America was split up the middle by a large interior seaway. The western shoreline was what is now Alberta, parts of Saskatchewan, Wyoming, Montana and other states farther south. Because coastal environments are ideal for fossil preservation we have a good record of the shoreline's inhabitants. In addition, marine sediments reveal a diverse fauna which included fish, sharks, turtles, lizardlike swimming reptiles called mosasaurs, and nessie-like reptiles called plesiosaurs, as well as birds, the latter grouped into the orders Hesperornithiiformes and Icthyornithiiformes.

The hesperornithiiform birds are unlike any modern representatives in one obvious way - they had teeth. North American genera included Hesperornis, Baptornis, and Parahesperornis, and all could not fly as evidenced by the unkeeled sternum and extremely small wings. They were piscivorous (fish eaters) and were specialized for footpropelled diving. Feather impressions of some species indicate that they possessed plumulaceous (down-like) feathers.
The ichthyornithiiform birds consist of only one genus, Ichthyornis. Unlike the hesperornithiiforms, Ichthyornis could fly but also had teeth. Besides the obvious predatory nature of this group, little else is known.

These toothed birds are found mostly in marine sediments of North America between the Turonian and Campanian Stages (between 91 and 74 million years ago). During this same time the sea transgressed and regressed, finally beginning to regress for good in the Campanian. When this sea finally withdrew so did the toothed birds. They became extinct. It is reasonable to assume that as the interior seaway withdrew, the niches that these birds occupied were lost. The toothed birds therefore experienced a slow, gradual extinction millions of years before the end of the Cretaceous.

Returning to the shorebird fauna of North America, we see that its representatives appear only near the end of the Cretaceous. Approximately 22 species are known. Presumably they derived from species not yet discovered. After the extinction event at the end of the Cretaceous, none of the species, genera or families are found. It must be assumed that something survived of the charadriiform birds to spawn the modern representatives of this order. Unfortunately the avian record immediately afterwards is poor until the late Paleocene of France, some 6-8 million years after the terminal Cretaceous extinctions. ${ }^{12}$

The avian record we now possess therefore shows two extinction events, one gradual (the extinction of the toothed birds) and one sudden (the extinction of most charadriiform species). The apparent sudden event that wiped out the dinosaurs 


\section{Table 1: North American Bird Species of the Late Cretaceous}

Abbreviations: Ce, Cenomanian, 97-91 million years ago (mya); Tu, Turonian, 91-88 mya; Co, Coniacian, 88-87 mya; Sa, Santonian, 87-84 mya; Ca, Campanian, 84-74 mya; Ma, Maastrichtian, 74-65 mya.

Species

Graculavus velox

G. velox?

Anatalavis rex

Laornis edvardsianus

Palaeotringa littoralis

P. littoralis?

$P$. vagans

Graculavid, gen. et sp. indet.

Tytthostonyx glauroniticus

Fam. et gen. indet.

Aves, incertae sedis

Alexornis antecedens

Lonchodytes estesi

L. pterygius

Torotix clemensi

Cimolopteryx rara

C. minima

C. maxima

Ceramornis major

$H$. regalis

$H$. altus

Parahesperornis alexi

Baptornis advenus

Ichthyornis sp.

Ichthyornis dispar

I. anceps

1. antecessor

Apatornis celer

Palintropus retursus

Enaliornis-like

Hesperornis crassipes
Telmatornis priscus

$H$. gracilis

Geological Stages

Source
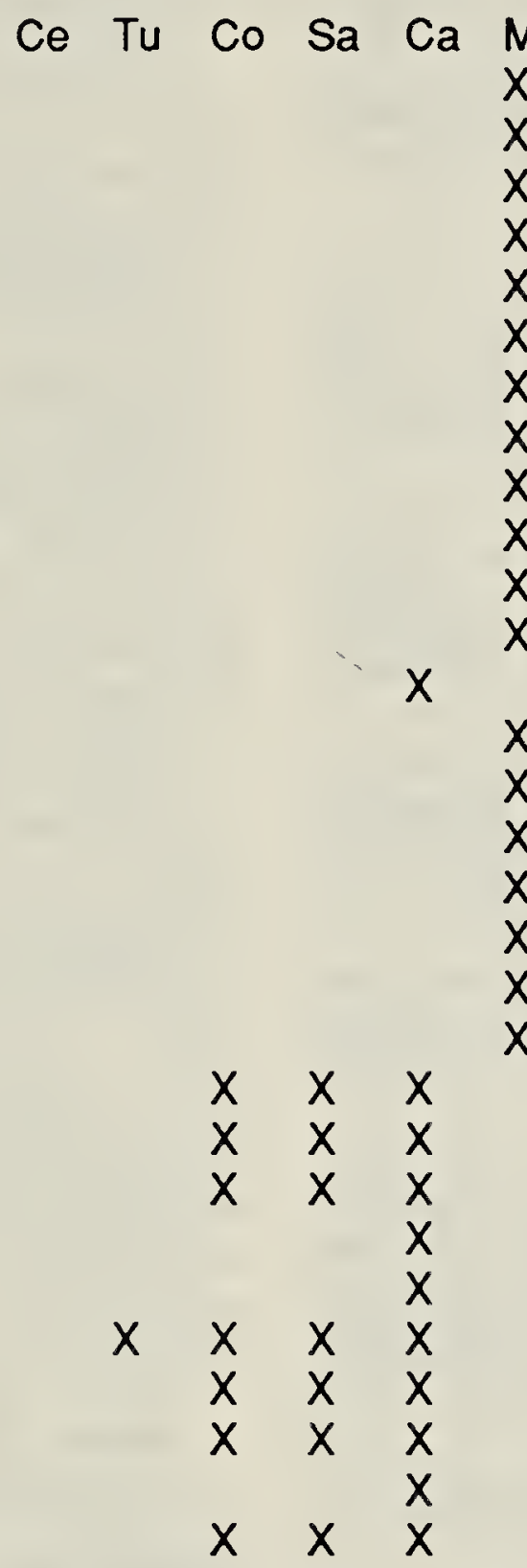

$x$

and affected other reptiles and mammals at the end of the Cretaceous appears also to be a causative agent in the second bird extinction. But unlike other groups of vertebrates whose post-Cretaceous relatives are known, the avian record is blank for several million years after the extinction event so we do not know how severe the extinction was among the birds. We may find, with future discoveries, that right above the boundary that marks the end of the
$\begin{array}{ll}\mathrm{Ma} & \\ \mathrm{X} & 18\end{array}$

$\begin{array}{ll}X & 18 \\ X & 18\end{array}$

$\begin{array}{ll}X & 18 \\ X & 18\end{array}$

$\begin{array}{ll}X & 18 \\ X & 18\end{array}$

$\begin{array}{ll}X & 18\end{array}$

$\begin{array}{ll}X & 18 \\ X & 18\end{array}$

$\begin{array}{ll}X & 18 \\ X & 18\end{array}$

$\begin{array}{ll}X & 18 \\ X & 18\end{array}$

$\begin{array}{ll}X & 18\end{array}$

$\begin{array}{ll}X & 18\end{array}$

X 18

$x-3$

$x-3$

$x \quad 3$

$x-3$

$x-3$

$x-3$

$X \quad 3$

$2,6,7,11,19$

6,11

$6,11,13$

13

15

$9,10,14,21$

11

11

24

11

3,4

12

6,11
$\begin{array}{ll}X & 18 \\ X & 18\end{array}$

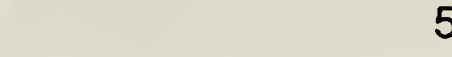

Cretaceous and the beginning of the Paleocene there was an avian fauna that resembles the Cretaceous fauna thus suggesting the birds were affected little by whatever extraterrestrial agent that caused the extinction of the dinosaurs. Or we could find a completely different fauna representing more modern lineages which would suggest some sort of rapid faunal turnover supporting a catastrophic extinction event. 
In the end we are left with another partially answered question. What really happened to the birds at the end of the Cretaceous? What were the predecessors of the shorebirds? At present, we just do not know for sure. This is confirmed by a recent report by Unwin. ${ }^{20}$ We can only work with what is at hand in the fossil record. The avian story is only beginning to unfold.

1. ALVAREZ, L., et al. 1980. Extraterrestrial cause for the Cretaceous-Tertiary extinction. Science 208:1095-1108.

2. BARDACK, D. 1968. Fossil vertebrates from the Marine Cretaceous of Manitoba. Canadian Journal of Earth Sciences 5:145-153.

3. BRODKORB, P. 1963. Birds from the Upper Cretaceous of Wyoming. Proceedings of the 13th International Ornithological Congress: 55-70.

4. 1970. The generic position of a Cretaceous bird. Quarterly J. of the Florida Academy of Science 32:239-240.

5. 1976. Discovery of a Cretaceous bird, apparently ancestral to the orders Coraciiformes and Piciformes (Aves: Carinatae). Smithsonian Contributions to Paleobiology 27: 67-73.

6. BRYANT, L.J. 1983. Hesperornis in Alaska. PaleoBios 40:1-7.

7. FOX, R.C. 1974. A middle Campanian, non-marine occurrence of the Cretaceous toothed bird Hesperornis Marsh. Canadian Journal of Earth Sciences 11:1335-1338.

8. 1984. Ichthyornis (Aves) from the Early Turonian (Late Cretaceous) of Alberta. Canadian Journal of Earth Sciences 21:258-260.

9. JARZENBOWSKI, E.A. 1989. Cretaceous insect extinction. Mesozoic Research 2:25-28.

10. LUCAS, S.G. and R.E. SULLIVAN. 1982. Ichthyornis in the Late Cretaceous Mancos Shales (Juana Lopez Member), Northwestern New Mexico. Journal of Paleontology 56:545-547.
11. MARSH, O.C. 1880. Odontornithes: a monograph of extinct toothed birds of North America. U.S. Geological Exploration of the 40th Parallel 7:1-210.

12. MARTIN, L.D. 1983. The origin and early radiation of birds. $\mathrm{Pp} .292-353$ in Perspectives in Ornithology. (A.H. BRUSH and G.A. CLARK, eds.). Cambridge University Press.

13. 1984. A new Hesperornithid and the relationships of Mesozoic birds. Transactions of the Kansas Academy of Science 87:141-150.

14. MARTIN, L.D. and J.D. STEWART. 1982. An Ichthyornithiform bird from the Campanian of Canada. Canadian Journal of Earth Sciences 19: 324-327.

15. MARTIN, L.D. and J. TATE. 1976. The skeleton of Baptornis advenus (Aves: Hesperornithiformes). Smithsonian Contributions to Paleobiology 27:36-66.

16. OLSON, S.L. 1975. Ichthyornis in the Cretaceous of Alabama. Wilson Bull. 87:103-105.

17. 1985. The fossil record of birds. Pp. 79-238 in Avian Biology, Vol. 3. (D.S. FARNER, J.R. KING, and K.C. PARKES, eds.). Academic Press, New York.

18. OLSON, S.L. and D.C. PARRIS. 1987. The Cretaceous birds of New Jersey. Smithsonian Contributions to Paleobiology 62:1-22.

19. RUSSELL, D.A. 1967. Cretacjous vertebrates from the Anderson River, Northwest Territories. Canadian Journal of Earth Sciences 4:21-38.

20. UNWIN, D.M. 1988. Extinction and survival in birds. Pp. 295-318 in Extinction and survival in the fossil record (G.P. LARWOOD, editor). Clarendon Press, Oxford.

21. WALKER, M.V. 1967. Revival of interest in toothed birds of Kansas. Transactions of the Kansas Academy of Sciences 70:60-66. 